\title{
Surfaces
}

\section{The subject of Exoticism: Victor Segalen's Equipée}

\section{Andreas Michel}

Volume 6, 1996

URI : https://id.erudit.org/iderudit/1064837ar

DOI : https://doi.org/10.7202/1064837ar

Aller au sommaire du numéro

Éditeur(s)

Les Presses de l’Université de Montréal

ISSN

1188-2492 (imprimé)

1200-5320 (numérique)

Découvrir la revue

Citer cet article

Michel, A. (1996). The subject of Exoticism: Victor Segalen's Equipée. Surfaces, 6. https://doi.org/10.7202/1064837ar
Résumé de l'article

Cet essai analyse l'Equipée de Victor Segalen, en conjonction avec la notion d'« exotisme " que l'écrivain interroge en tant que concept philosophique. Il démontre comment l'exposition à une différence radicale (l'« exotique ") mène à une déstabilisation du sujet même, qui se fait et se défait au contact avec autrui. De même, ce texte montre comment l'Equipée met en évidence la manière dont Segalen envisage le sujet : un processus d'émergence continue.
Copyright (C) Andreas Michel, 1996

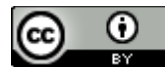

Ce document est protégé par la loi sur le droit d'auteur. L'utilisation des services d'Érudit (y compris la reproduction) est assujettie à sa politique d'utilisation que vous pouvez consulter en ligne.

https://apropos.erudit.org/fr/usagers/politique-dutilisation/ 


\title{
The subject of Exoticism: Victor Segalen's Equipée
}

Andreas Michel

Indiana University

Dept. of Germanic Studies

amichel@juliet.ucs.indiana.edu

Surfaces Vol. VI.1 (v.1.0A - 15/12/1996) - ISSN:

1188-2492

Copyright for texts published in Surfaces remains the property of authors. However, any further publication should be accompanied by an acknowledgement of Surfaces as the place of initial publication.

\begin{abstract}
This essay analyzes Victor Segalen's Equipée in conjunction with Segalen's exploration of the notion of "exoticism" as a philosophical concept. It demonstrates how exposure to radical difference (the "exotic") leads to a destabilization of the self-same subject which is made and unmade in the contact with otherness and how Equipée enacts Segalen's vision of the subject as a process of continuous emergence.
\end{abstract}

\section{RÉSUMÉ}

Cet essai analyse l'Equipée de Victor Segalen, en conjonction avec la notion d' exotisme que l'écrivain interroge en tant que concept philosophique. Il démontre comment l'exposition à une différence radicale (l' exotique ) mène à une déstabilisation du sujet même, qui se fait et se défait au contact avec autrui. De même, ce texte montre comment l'Equipée met en évidence la manière dont Segalen envisage le sujet: un processus d'émergence continue. 
The writings of Victor Segalen (1878-1919), a turn of the century French marine officer, poet, and travel writer, have only recently received significant attention.[ $\underline{\mathbf{1}}$ ] In the contemporary climate of new forms of cultural criticism and the attention given to discourses of difference, otherness, and alterity in general, Segalen's critique of ethnocentrism, colonialism, and exoticism has rightly been considered as an early example of such recent approaches to Western cultural hegemony. Segalen has been hailed primarily for Les Immémoriaux, [ 2 ] a novel about the inhabitants of Tahiti before the islands were settled by Europeans. In this novel, told from the perspective of a non-European narrator, Segalen focuses on the destruction suffered by the indigenous population of the Polynesian islands at the hands of Western civilization.

Les Immémoriaux represents, however, Segalen's only directly political critique of the consequences of Western influence. In his subsequent writings, he became interested in the philosophical implications of cultural difference and the desire for the Other. In this exploration, he tried to come to terms with the attraction that exoticism held for him on a personal level, on the one hand, and its destructive effects brought about in the clash of different cultures on the other. He attempted to develop a theory of exoticism that would formulate the essence of the encounter between different cultures. This philosophical inquiry, Segalen felt, had to address the way in which Western thought, through the concept of the subject, theorized the relation to otherness in general.

In this essay, I would like to demonstrate that Segalen's writings, through their reflection on the 'essence of exoticism,' formulate a break with modernity in that they rearticulate the notions of the subject and of experience. [ $\underline{\mathbf{3}}$ ] Segalen's aesthetic reflections, which originate in aestheticism, i.e., on the most pronounced edge of aesthetic modernism, take leave of the modern paradigm as a result of his travels to non-European destinations.

In my investigation, I focus on a travel narrative that Segalen wrote upon returning from his 1914 archaeological expedition through China. His journey resulted in two books that belong to two different genres. While The Great Statuary of China[ $\underline{\mathbf{4}}$ ] can, with some reservations, be seen as a traditional 
archaeological account within the bounds of science, Equipée,[ $\underline{\mathbf{5}}$ ] the book that I would like to discuss here, is a work of imaginative literature. It represents, like all of Segalen's work, a testing ground for the encounter with otherness.

I.

Rendering the cultural Other exotic, and by that token either inferior or superior to the European gaze, has a long tradition in Western modernity. Ever since the age of exploration and discovery, which inaugurates the expansionism of the West, there has emerged a stream of literary, scientific, and philosophical representations of exotic peoples and places. These peoples are more often than not judged and classified from the position of a purportedly universal reason. In their introduction to a recent account on exoticism during the Enlightenment, the authors describe the faith of the West in the superiority of the classificatory power of the mind in the following terms:[ $\underline{\mathbf{6}}$ ]

Science, industry and empire, belief in universal natural laws, eternal norms of truth, justice, morality, beauty and so forth-all these desiderata constitute creeds widely espoused in that developed world whose inhabitants refer to themselves as the "West" (a cultural more than a geographical entity). These beliefs eliminate the resistance, the anxiety, provoked by the alien. Strange terrains are mapped, bizarre species classified, weird customs interpreted, order imposed. Elimination may even be literal, as with the fates of many Indian tribes in the Amazon basin in our own century. [Rousseau and Porter (1990), 1]

This account of reducing cultural difference to the grids of Western conceptual thought points to the mechanism with which, consciously or unconsciously, non-Western peoples and their customs and knowledges were 'taken care of.' Their 'alien' identity, as seen from the cultural center, has been explained away through 'objective' methods of classification: science, philosophy, and morality. The West, in other words, had not only developed mechanisms to defend against the strangenenss of the encounter with cultural Others, but it had also devised ways of doing away with their 
strangeness altogether. Cultural Others could be reduced to the grid that the West already had in place. Otherness, in other words, represented not a challenge to be encountered but rather an object to be classified.

This attitude towards cultural difference can also be witnessed in the aesthetic realm. Nineteenth-century travelogue writers, imbued with the ideas of European superiority on the evolutionary ladder of humanity, often represented non-European peoples as communities in a state of innocence. The specificity of the term 'exoticism' as distinct from 'primitivism' perhaps takes on its meaning in this context of a paradise forever lost to civilization. Non-Europeans find themselves eulogized wherever they can be found, their world reduced to the projections of Europeans wary of civilization-for civilization, while remaining the point of reference for any judgment, is considered the fallen state of society. At the turn of the century, technology, bureaucracy, political disarray, poverty, and class differences testify to this fact. The exoticist traveled to enjoy the otherness of cultures which, in his view, were innocent, beautiful: communities that knew no strife.

At the tail-end of these nineteenth-century travelers from colonial countries was the Frenchman Victor Segalen who, during the first two decades of the twentieth century, traveled to the South Seas and to China. There can be little doubt that he saw himself as an exoticist, perhaps one of the purest, if by exoticist is meant someone who enjoys the experience of radical cultural difference. To submit to the lure of faraway places, to capture their nature, and to communicate this experience in literary works, became his passion. From this perspective, Segalen certainly is part of the tradition of exoticism.

\section{II.}

Segalen's understanding of exoticism is, however, of a different nature than that of most travel writers before the twentieth century, as exemplified by the following passages from his Essai sur l'exotisme.[ 7 ] This collection of notes represents the heart of Segalen's philosophical enterprise. It collects his thoughts on the contact with non-European cultures and elevates that contact to the theoretical and aesthetic problem par excellence. 
At the center of his dissatisfaction with the representations of other cultures is the French tradition of literary exoticism, those narratives that bear the names of Bernardin de Saint-Pierre, Chateaubriand, Loti, Saint-Pol-Roux and Claudel. He therefore desires to distinguish his own 'exotic' writings from those of his predecessors or contemporaries. This requires a change of perspective: Mais quoi? Des 'impressions' de voyages, alors? Non pas! Loti en donne, à revendre $(E E, 31)$. Visions of coconuts and tropical skies $(E E, 63)$ are not for him. He disdains these depictions because they lack, despite their appearance, in aesthetic rigor. The authors of such tales are purportedly interested in difference and otherness. In reality, however, their focus has not been on the other culture but merely upon their own reactions.

Ils ont dit ce qu'ils ont vu, ce qu'ils ont senti en présence des choses et des gens inattendus dont ils allaient chercher le choc. Ont-ils révélé ce que ces choses et ces gens pensaient en eux-mêmes et d'eux? Car il y a peut-être, du voyageur au spectacle, un autre choc en retour dont vibre ce qu'il voit. Par son invention, parfois si malencontreuse, si aventurière (surtôut aux vénérables lieux silencieux et clos), est-ce qu'il ne va pas perturber le champ d'équilibre établi depuis des siècles? Est-ce qu'il se manifestera pas autour de lui, en raison de son attitude, soit hostile, soit receuillie, des défiances ou des attirances? ... Tout cela, réaction non plus du milieu sur le voyageur, mais du voyageur sur le milieu vivant... (EE, 31-32)

According to Segalen, then, traditional exoticism has depicted only one side of the encounter, i.e., the experience of the European subject that, in search of the thrill of exoticism, merely recounted and represented its own vision. As a rule, exoticist writing neglected to portray its own impact on the culture that was the object of its gaze. Therefore his maxim: in exotic writings one should attempt not to crudely tell one's vision, but through an instantaneous, constant transfer, tell of the echo of one's presence $(E E, 32)$. This leads him to a number of theses for a reformulation of exoticism:

L'exotisme n'est donc pas cet état kaleidoskopique du touriste et du médiocre spectateur, mais la réaction vive et curieuse au 
choc d'une individualité forte contre une objectivité dont elle perçoit et déguste la distance. (Les sensations d'Exotisme et d'Individualisme sont complémentaires).

L'exotisme n'est donc pas une adaptation; n'est donc pas la compréhension parfaite d'un hors soi-même qu'on étreindrait en soi, mais la perception aiguë et immédiate d'une incompréhensibilité éternelle.

Partons donc de cet aveu d'impénétrabilité. Ne nous flattons pas d'assimiler les moeurs, les races, les nations, les autres; mais au contraire éjouissons-nous de ne le pouvoir jamais; nous réservant ainsi la perdurabilité du plaisir de sentir le Divers. $(E E, 38)$

In Segalen's view, then, traditional travel writing was vitiated from the start because it employed an uncritical subject of knowledge as the narrative center of experience. Susceptible to cultural and phenomenal difference and attempting to represent otherness from within its own history, perspective, and point of view, Segalen was subsequently led to consider not only the cultural differences between Western and non-Western peoples, but also to confront, in the construction of subject and object, the epistemological underpinnings of Western thought.

Segalen's life-long preoccupation with non-European cultures is thus fueled by the desire to preserve difference rather than by fear of the other or by the unquestioned premise of the superiority of Western civilization. Thus, what distinguishes his writings from those of many of his predecessors (as well as some of his successors) is his championing of the concept of diversity rather than unity. Segalen was convinced that he had found the justification for his conviction in the experience traditionally called exoticism, i.e., the attraction and the shock that le divers (difference, otherness, alterity) exercises upon the traveler. The notions of diversity and of the subject lead Segalen to present Equipée as an inquiry into as well as a dramatization of the aesthetic attitude toward knowledge of the other.

Equipée, while nominally following the itinerary of the expedition in China, represents an exploration of the clash of the two fundamental tendencies in which aisthesis has been thought in the West: as sensory encounter with the physical world ( experience ), on the 
one hand, and as imaginative, poetic construction of the world ( imagination ) on the other. In Equipée, Segalen, the poet, undertakes a journey into the land of the real ( un voyage au pays du réel )-the subtitle of Equipée-in order to find out if the power of the imagination can hold its own when confronted with brute reality $(E, 53)$ or if, on the contrary, the knowledge furnished by the imagination has to be discarded.

\section{III.}

As is well known, the term aesthetics derives from the Greek aisthesis which refers to sensory perception in the most general sense. Thus, aesthetic experience, as the sensible link to the world outside, can be seen as precondition for scientific knowledge. In modernity, however, and since the eighteenth century in particular, the aesthetic attitude came to be identified with art alone, more specifically, with the production and reception of works of high art. While this modern conception of aesthetic experience is certainly not unrelated to the Greek meaning of aisthesis, its concentration in a separate, quasi-autonomous social sphere, favored a distinct development of art driven by a logic all its own.[ $\underline{\mathbf{8}}$ ]

One consequence of this compartmentalization of art was the birth of aesthetic ideology, by which I mean the belief that the intuitive knowledge of the artist could supplant the knowledge gained through sensory experience. This aesthetic ideology culminates, towards the end of the nineteenth century, in the literary movements of decadence and aestheticism in which the sensory experience of the outer world (reality, the object) has been replaced by a stress on inner vision alone. A notion like poésie pure, for example, refers primarily to a form of poetic practice where any relation to an outside world (through aisthesis) is viewed as superfluous. By the same token, all claims to more mimetic modes of literary representation, such as realism or naturalism, found themselves relegated, by the proponents of aestheticism, to the ashheap of history. In philosophical terms, such a rejection of the outside leads to an extreme form of idealism. Any cognitive potential that works of art might hold, now originated exclusively in the mind of the artist as genius who, on the basis of superior sensibility, was held to be able to 
bring true knowledge into the world in the form of imaginative representations. These representations, because they point to the essence of things, were held to embody a knowledge greater than that which can be gained through sensory experience alone.

When Segalen, in 1902, published his first essay entitled Les Synesthésies et l'école symboliste, he was still very much influenced by this tradition.[ $\underline{\mathbf{9}}$ ] In his article, Segalen is concerned with a defense of the literary vanguard of his time and its aesthetic practices.[ 10 ] Synaesthesia, "denoting the perception, or description of the perception, of one sense modality in terms of another," has been a traditional feature in Western literature, although it has sometimes been seen as "a sign of illness, degeneration or decadence." Furthermore, while such a judgment of decadence probably stems from prejudice or ignorance, "synaesthesia occurs very widely in language and literature in an apparently universal role among civilized (!) peoples as the metaphor of the senses."[ $1 \mathbf{1 1}]$

With his focus on synaesthesia, Segalen has taken up a topic that is very much at the forefront of reflections on aesthetic experience during the latter part of the nineteenth century. Baudelaire's Correspondances, Rimbaud's Voyelles, Jules Millet's thesis on Audition colorée, as well as Huysmans' A rebours, all testify to this fact. What unites these writings despite their differences is the poetic vision assigned to the mutual interpenetration of the senses. Audition colorée, for example, is the denomination for a poetic practice which is supposedly able to establish essential links between sound and color of a given experience. In his essay, Segalen wants to fix in bold strokes the logically acceptable deductions which make synaesthesia into powerful artistic tools $(S, 21)$. He distinguishes between a primary and a secondary sensation: a primary sensation of any kind (e.g., a sound) is accompanied by another, secondary one (e.g., a color) which Segalen calls sensation-echo or simply echo $(S, 23-24)$. This secondary sensation has been induced by the primary one, accompanies it now, and, in the case of hallucinations, may replace the primary one.

Two points are of interest to me in this context. First, Segalen emphasizes the subjective character of the second sensation. Time and again in the essay Segalen maintains that, although real and worth scientific exploration, the synaesthetic quality of different sensations originates in the subject itself. Synaesthetic sensations are neither objective, nor objectifiable in 
general. They stem from the interior recesses of a mind that has genius-like recourse to the inner harmony of things. And, Segalen argues, it is the poet who makes the greatest use of synaesthesia to reveal the essence of things beyond their appearance.

The second point is intimately linked to the first. It concerns the fact that the harmony in things achieved via synaesthesia is a figure of unity. This becomes quite clear in the context of Segalen's polemical rejoinder to Max Nordau's equally polemical theses on the state of modern art in his famous work Dégénérescence.[ 12 ] In Nordau's view, modern developments in art, including the practice of synaesthesia, are a throwback to a premodern state of undifferentiation. He maintains that any achievements in modernity are, on the contrary, due to a constant process of differentiation in all fields of human endeavor and that, consequently, the attempts at non-differentiation made by modern artists-as evidenced, for example, in the desire to experience the nondifferentiated simultaneity of distinct senses-ought to be condemned.[ 13 ] Segalen advances the following quotation from Nordau as proof of Nordau's belief in the (natural) linearity of evolutionary history:

Le développement naturel va toujours de l'Unité à la diversité, énonce-t-il, et non au rebours. Le progrès consiste dans la différenciation et non dans le retour des êtres différenciés et d'une riche originalité à une archaïque gélatine sans physionomie... $(S, 47)$

Segalen answers this challenge through a philosophy of history of his own. Nordau, he maintains, simply confuses the origin of evolutionary development (which Segalen also locates in an undifferentiated chaos that subsequently evolves into a state of order) with the present stage of evolution, in which the time has come for a synthetic approach to phenomenal differences. This synthetic tendency $(\mathrm{S}, 47)$ is, according to Segalen, the sign of the times in the sciences as well as in philosophy:

C'est enfin l'allure même du mouvement philosophique actuel: passer du même à l'autre (Hegel), relier par une dialectique rationnelle les diversités du monde sensible, s'approcher ainsi du terme dernier de la connaissance qui doit être une Hétérogénéité cohérente (Spencer). $(S, 48)$

The problematical term 'coherent heterogenity' is at the time of Les synesthésies weighted in favor of coherence 
and systematic harmony, as exemplified by the attempt to approach the last term that would unify the whole. This, maintains Segalen, is the desire of the synthetic tendency of the times. However, it is of course quite obvious that one might also reverse the perspective and tip the balance of this term in favor of heterogeneity. This is in fact what happens when Segalen turns to exoticism. In the context of Les synesthésies, however, the combination of subjective sensations and the harmony of things promised by synaesthetic vision transport its fashioner to the position of world-maker. While this position is nothing new, neither for the poet nor the philosopher, it occurs in aestheticism without recourse to outside experience. In this sense, aestheticism can be seen as sensation without experience.

It is precisely this conceptual field of subjectivity, harmony, and unity (the essence of synaesthetic practice) that Segalen rejects when he formulates his theory of exoticism. In a notebook entry destined for his Essai sur l'exotisme, Segalen writes on 21 February 1909:

La différenciation des arts entre eux; ce qui est propre à la musique, à la peinture, etc., le contraire des synesthésies. La palinodie. Palinodie de mes synesthésies. (EE, 52-3)

With these words, Segalen dismisses, along with synaesthesia, the school of aestheticism that he had defended in his early article. He does so, however, by means of a radicalization of one of the aspects so dear to aestheticism: namely the refinement of the senses. Segalen's interest in the sensory aspect of life leads him to undertake his journeys to Polynesia and China, to explore different climates and cultures. - From this contact stems his need to reevaluate-and ultimately revalue-the actual sensory experience as otherness and to develop his philosophy of exoticism. In other words, Segalen's personal desire to encounter non-European peoples, traditions, belief systems, his interest in otherness, difference, and diversity as ways of enhancing personal experience, in short: his exoticism, leads him beyond the pale of aestheticism's refined idealism and towards a theory of difference. 


\section{IV.}

As a medical officer in the French navy, Segalen's wish to see foreign countries can, for obvious reasons, be easily granted. And since, in his view, greater distance leads to greater pleasure, he travels to the most distant parts of the globe. In geographical and cultural terms, the greatest distance for him as a European is represented first by Polynesia, and then by China. As I demonstrated above, Segalen is well aware of the name for his attraction to these faraway lands-exoticism-as well as the negative connotations that this term holds. Yet he feels that the essence of this word has not been sounded in a satisfactory manner. For apart from its geographical and cultural application, the idea of distance, in which he sees the essence of exoticism, also expresses the philosophical relation between subject and object. And it is at this point that his exoticism takes on theoretical dimensions.

This dimension of exoticism, then, is directly linked to an always renewed experience of difference and alterity. In his encounters with different cultures, Segalen is intent on reviving the level of aesthetic experience that had been devalued in aestheticism: direct sensory experience through physical contact. In this perspective, Segalen's own contribution to intellectual history comes into view: it consists in his desire to reintegrate sensory experience into his poetic writings. This does not proceed without a struggle. While Segalen the aestheticist believes in the evocative power of the imagination, Segalen the traveler explores the sensible nature of experience. Equipée, this trip in the land of the real, stages the debate between these two versions of aesthetic experience.

C'est donc à travers la Chine, grosse impératrice de l'Asie, pays du réel réalisée depuis quatre mille ans, que ce voyage se fera. Mais n'être dupe ni du voyage, ni du pays, ni du quotidien pittoresque, ni de soi! La mise en route et les gestes et les cris au départ, et l'avancée, les porteurs, les chevaux, les mules et les chars, les jonques pansues sur les fleuves, toute la sequelle déployée, auront moins pour but de me porter vers le but que de faire incessament éclater ce débat, doute fervent et pénétrant qui, pour la seconde fois, se propose: l'Imaginaire déchoit-il ou se renforce quand on le confronte au Réel? $(E, 16)$ 
During the expedition that takes him across the Chinese continent, Segalen opposes the imaginative practice of the poet and his tools, words, to the physical experience of the traveler. Poet and traveler are, of course, the same person, mind and body the different poles of experience. In addition, the two opposing aesthetic attitudes, l'imaginaire and le réel are shorthand for two different modes of access to knowledge, namely contemplation and action. The mode of contemplation refers to intellectual, abstract, and imaginative pursuits whereas the kind of knowledge provided by action stems from the sensory, concrete, and material engagement with physical reality. However, rather than see the latter, in the tradition of Western philosophy, as the mere precondition of the former, Segalen stages a debate between these two modes of perception.

Equipée is structured in such a way that the reader witnesses the imaginative anticipation (l'imaginaire) of an experience followed by a narrative of its actual occurrence (le réel). More often than not, the imaginative projection is proven to have been false, the actual experience taking place in a manner quite different from what the narrator had expected. The different chapters thus show the traveler being shaken to and fro between the two worlds of imagination and reality.

While every chapter stages the debate in different terms with slightly different implications-the sequential logic of which would, in fact, be deserving of a separate study-I would like to concentrate on three examples which, I hope, will support my claims concerning Segalen's critique of modernity. I have chosen the first example to point to Segalen's description of the deficiencies of rational calculation when confronted with sensory experience. The second example demonstrates in similar fashion how the imagination of the poet runs into trouble when confronted with physical reality. The third example will serve to introduce the fundamental point regarding Segalen's theory of exoticism, namely the notion of shock.

Before he sets out on his journey, the narrator of Equipée feels the need to plan the trip as well as he can so as to be prepared for any kind of eventuality (section 4 ). But he is suddenly seized by doubts, even fears, when he imagines his confrontation with the real:

Pris d'un doute plus fort que tous les autres, pris tout d'un coup du vertige et de l'angoisse 
du réel, je rappelle et j'interroge un à un les éléments précis sur quoi s'établit l'avenir. Ce sont des relations de voyage, (des mots encore), des cartes géographiques-purs symboles, et provisoires, car des districts entiers sont inconnus là où je vais. Il $\mathrm{y}$ a donc les chenilles sépia des montagnes; des traits rouges pointillés qui marquent à l'aventure les routes ouvertes, inexistantes peut-être. Des traits bleus qui dessinent les fleuves; des traits verts qui représentent les limites des provinces ou des Etats. Quelle sera la possibilité de franchir l'un ou de sauter l'autre? Le fleuve a peut-être un pont ici; et la frontière politique un prétexte à n'être pas enjambée. Enfin il y a le problème de pure longueur dans l'espace que tout ce chemin représente. $(E, 19-20)$

The narrator's doubts and fears arise from the fact that the map, i.e., a cognitive representation, is inadequate. Although he can read the markings perfectly well, he fears that this representation will not be of any help for he suspects that the map will turn out to be an insufficient tool when it comes to the physical experience of the actual territory. Similarly, the curvimeter, a means to measure distance on the map, is feared to be inadequate.

Et voici la roulette d'acier du curvimètre qui se tortille et virevolte entre mes doigts, progressant terriblement vite sur son axe enspiralé. Elle fait sa route avant moi, et puis, reporté sur la barre rigide de l'échelle, elle donne, sans commentaires, des mesures précises, précises au centième, - mais fausses; car pour un détour du trait sur la carte, la route en a peut-être fait deux sur la plaine, et dix et vingt sur la montagne. $(E, 20)$

The curvimeter's measurements are unreliable because they are dependent upon the map. While its measurements are accurate within one hundredth of a percentile, all the curvimeter can measure are the distances as represented by the map. And these distances are abstract, because they do not, cannot, mimetically convey every turn of the actual landscape. Thus, while the measurements of reason and its representations are inaccurate at best, Segalen here calls them downright false. But this presents a problem: 
Il ne faudra point avoir tort. Derrière ces mots, derrière ces signes figurés, étalés conventionnellement sur le plan fictif d'un papier, il me faudra deviner ce qui se trouve très réellement en volumes, en pierre et en terre, en montagnes et eaux dans une contrée précise du monde géographique. $(E, 21)$

He needs to know what is behind the map, behind the words and conventional signs, in order to plan his trip. The abstract representations of reason are of no help here. That's why the narrator resorts to the other possibility: imagination. When, embarked on his trip, he comes to the first mountain range (section VII) to be scaled, the narrator is exalted by images conveyed to him through words alone. In view of the mountain peaks, he hears souffler de grands mots assomptionnels; et le vent des cimes, et la contemplation de la vallée, la conquête de la hauteur, le coup d'aile... And he asks himself: Cette exaltation vaudra-t-elle, à l'expertise, un seul coup de jambes sur le roc? $(E, 28)$

Thus, at the foot of the mountain, the narrator employs the other mode of representation, the sensibility of the poet who constructs experience on the basis of language and its sedimented meanings. The ring of words produces in him an imaginative response outside of any sensory experience. His skeptical question as to whether the physical experience of the real (the actual climb) will resemble in any way the sensation evoked by these words, introduces, of course, the basic theme of Equipée Equipée. And thus begins the debate.

From the outset, the narrator needs to correct his preconceptions. He is forced to adjust the imaginary representations of the ascent in light of his experiences in the territory. The path up the mountain, for example, rather than leading straight up, descends at first before it goes up. Similarly, the shortest way to the mountain top, which lies straight south, is to proceed in the direction of less noble coordinates $(E, 29)$ rather than proceeding straight south. The circuitous route is in fact the shortest, because the only possible route. After this learning process, the narrator concludes:

N'interrogeons plus les mots ou bien ils crèveront de rire d'avoir été gonflés de tant de sens encombrants. [...] Mais j'imaginais tout autre la domination divine de la montagne; jeter un pont d'air brillant de glace et planer en respirant si puissament que chaque 
haleinée soulève et porte... Je n'en suis pas encore là... J'ai peut-être confondu des verbes différents: ascension, assomption. (E, 29-30)

However bad the narrator deems this last jeu médiocre de mots (E, 30) to be, it raises the issue I am concerned with quite succinctly, if in slightly ironic fashion. Because of the partial homophony between ascension and assomption, the traveling poet, in the narrator's pun, can be easily misled in his conception of what it takes to climb the mountain. Ascension and assomption merge in their different yet related fields of meaning. When merged, the two words cover the spiritual meanings of Christ's and Mary's ascent to heaven as well as the secular ones of hypothesis or mere assumption. These meanings infiltrate and impinge upon each other in the poet's mind so that ascension as the actual physical scaling of the mountain is a confused mix of different significations-as long as it happens only in language.

This self-ironic comment can be read, on the one hand, as a jab at aestheticism which contemplates the essence of things on the basis of correspondences. On the other hand, it can be seen as a comment on the logic of signification as such. What Segalen alludes to here, is the knowledge, so pervasive since de Saussure and Jacobson, that, as signifiers, words entertain very different contiguities with each other than they do as signifieds, as meanings.

In the context of Equipée, however, both levels of signification are tested against their outside, i. e., the referent to which they refer. The physical experience of the trip exposes an otherwise unnoticed process of signification and curbs the representational claims of the imagination. Sensory experience, in other words, checks the abstract nature of words and forces a recognition of the difference between imagination and reality. The mediocre word-play thus captures in an efficient manner how insufficient a poet's imaginary constructions can be when confronted with reality.

The two examples, map and word-play, exemplify the limitations of reason and imagination as abstract constructions of the mind. The specificity of Segalen's writings lies in his departure from the aestheticist espousal of the truth of the poetic imagination. Segalen here seems to doubt the imagination's representational claims as much as those of reason. It is this aspect of his work that challenges the discourse of modernity, for Segalen here sidesteps an opposition that can be called the modern antithesis per se, reason and imagination. 
Conceived as competing models of cognition, reason and imagination span a long history of adversity when it comes to their role in the construction of knowledge. If it is correct to say that, in Segalen's conception, l'imaginaire, as the depository of words, comprises both reason and imagination which are opposed to direct physical experience, then Segalen's inquiry goes beyond the modern antithesis. In fact, it leads to the limits of the discourse of modernity. By combining the imaginative and the rational faculty in his notion of the imaginary, Segalen puts the modern structure of knowledge in doubt. What is at issue when the reliability of words in general is questioned is the status of representation as such. If such is the case, Segalen may be said to glimpse the limits of modernity's attempts at self-transcendence in the direction of a utopian state of harmony and resolution of conflict.

I have furnished two examples to support my reading; many more could be supplied. What is more pressing, however, is to determine what vision Segalen counterposes against the tradition. In order to do this I will move on to my third example.

It is quite obvious that this example must bring the term exoticism into play, for this is after all the task that Segalen had set for himself: redefine exoticism in such a way that it comes to stand for a philosophical vision in its own right. And it is at the end of his journey, when the narrator takes stock of the experiences furnished by the debate that the reader is initiated into the trip's intellectual gains. After thinking back on the different stages of his journey and the constant clash of l'imaginaire and le réel, the narrator observes:

De cette opposition constante entre les deux mondes s'est tirée une autre leçon. Un autre gain; une acquisition impérissable: un acquet de plaisir du Divers que nulle table des valeurs dites humaines ne pourrait amoindrir.

C'est qu'en effet, partout où le contact ou le choc s'est produit, avant toute expertise des valeurs en présence, s'est manifestée la valeur du divers. Avant de songer aux résultats, j'ai senti le choc ainsi qu'une beauté immédiate, inattaquable à ceux qui la connaissent. Dans ces centaines de rencontres quotidiennes entre l'Imaginaire et le Réel, j'ai été moins retentissant à l'un d'entre eux qu'attentif à leur opposition. (E, 130-131) 
This passage contains the entire vision of Segalen's exotisme comme une esthétique du divers. Here it becomes clear why, in Equipée, he undertook the inquiry into the two different aesthetic attitudes. For Segalen, aisthesis, the aesthetic attitude is the fundamental prerequisite for his theory of exoticism. Only the aesthetic attitude, through the pleasure provided by the senses, can guarantee his vision of exoticism as a theory of difference. Segalen's aistheticist metaphysics does not champion a rarefied sensibility as the gateway to knowledge. Rather, as quasi-transcendental ground, it specifies the condition of possibility for the emergence of difference. In Segalen's view, this emergence is possible only on the basis of a shock, the sensory contact with something other than the subject, something exotic to the subject. This value of difference, otherness, exoticism is more fundamental than (and logically prior to) any other value. As is clear from the above passage, Segalen's metaphysics is therefore neither a theism nor a humanism: it is not held in check by an ethical imperative or the harmony of faculties. Rather, it is an exoticism that tries to accommodate a metaphysics of difference.

Au-delà de tout-au-delà du bonheur ou du satisfait--au-delà de la justice et de l'ordre... demeure la certitude que voici; la justification d'une loi posée de l'exotisme-de ce qui est autre-comme d'une esthétique du divers.

Mais il faut s'entendre: le Divers dont il s'agit ici est fondamental. L'exotisme n'est pas celui que le mot a déjà tant de fois prostitué. L'exotisme est tout ce qui est Autre. Jouir de lui est apprendre à deguster le Divers. $(E, 131)$

To enjoy difference remains the primary motivation of Segalen's metaphysics. Part and parcel of this metaphysics is a theory of difference that rearticulates the notion of the subject to which I will turn in the last section. With respect to the debate in Equipée, Segalen notes that, in the end, neither of the two aesthetic attitudes won out over the other. In the narrator's judgment, these attitudes neither cancel each other out, nor can one be subsumed under the other. He concludes that his experiment supports the thesis of difference and distance that he calls exoticism. What held good throughout his journey was the amount of pleasure that the trip gave him. This is the case precisely because the debate itself, the distant, or exotic, nature that divides 
the imagined world from the world of physical experience-the clash itself-is the reason for his pleasure.

Equipée, with its debate between two different aesthetics, then, is designed to serve as an exemplification of Segalen's theory of exoticism. In his eyes, his exploration proves that the fundamental nature of pleasure consists in the experience of the shock between two incommensurable entities-in this case, two opposed aesthetic attitudes. And this aesthetics of shock entails a theory of difference.

\section{V.}

It is time to inquire into the nature of this shock and the pleasure associated with it. Equipée demonstrates that Segalen's notion of pleasure does not result from the subject's plan, design, and desire. The shock that Segalen searches out in his exotic travels can neither be produced on demand nor can its nature be described or anticipated. The enjoyment that he felt resulted from the clash of two aesthetic attitudes, not from a feeling of seing something anticipated turn into reality. Thus, the pleasure connected with the experience of the shock affords the subject no mastery. Pleasure can be sought out (i.e., one can travel to exotic lands, and prepare for the shock of difference) but it cannot be controlled because it emerges only when unexpected.

What does this view of aesthetics imply for the subject of modernity? The predominant view of the modern subject is as a subject of knowledge. Its essence is first and foremost described in cognitive terms so its activities can serve as the foundation for the scientific attitude. In contact with the physical world, however, the subject always negotiates the sensory impact with the requirements of the mind in order to produce representations. In order for these representations to come about, there has to be a harmonious interplay between the senses and the mind. In this set-up, the sensual impact has been directly related to the establishment of harmony of the senses with the mind-so that difference, otherness, alterity would not destabilize the subject but rather serve to support its productions of knowledge. Difference, in this scenario, can appear only to the extent that it is compatible with the laws of the modern mind. 
Segalen's vision of the subject departs from this view because he sets out from aesthetics. The aesthetic subject, according to Segalen, is constituted not as the result of a harmony between the senses and the mind but rather as a result of a shock beyond its control. Pleasure happens to the subject in the form of an unplanned event, and constitutes it in that moment. In this sense, the aesthetic subject is a result of an event that is exotic to it, and that will therefore partially elude its grasp. In this encounter there remains a rest, an excess, which the aesthetic subject cannot contain or represent.

In one of the notes collected in his unfinished Essai sur l'exotisme, dated 21 octobre 1911, Tientsin, Segalen comments on the phenomenology of the aesthetic encounter between the subject and the object in the following manner. Refering to the object, he says:

Le pouvoir de sentir le Divers contient [...] deux phases, dont l'une réductible: l'un des éléments divergents est nous. Dans l'autre, nous constatons une différence entre deux parties de l'objet. Cette seconde doit se ramener à la première si l'on veut en faire une sensation d'exotisme: alors le sujet épouse et se confond pour un temps avec l'une des parties de l'objet, et le Divers éclate entre lui et l'autre partie. Autrement pas d'exotisme. (EE, 66-67)

What Segalen describes as the second part of the object is the excess that makes possible the aesthetic encounter in the name of pleasure. In order for there to be the kind of pleasure that Segalen interrogates in his writings, the subject itself has to be conceived not in terms of mastery, but rather, at least partially, as a reaction to the sensual data in connection with which it first finds itself. Its identity is thus partially gained and lost in every shock, in every exotic moment. Segalen's inquiry into exoticism via this unusual travel account has led to a conception of the subject whose identity, rather than being stable, can be said to be in a constant state of emergence. The aesthetic subject searches out the exotic (that which is different from itself) in order to be displaced, in voluntary yet involuntary fashion. In this activity, Segalen sees the philosophical essence of exoticism.

Thus, the impact of difference, or the fact of exoticism, can be registered only in the displacement of the aesthetic subject. This displacement, however, no longer 
enables the subject to produce a true representation of the encounter-even less of the object-nor can it be determined beforehand what consequences the encounter entails.

\section{NOTES}

1. See for instance Marc Gontard, Victor Segalen. Une esthétique de la différence (Paris: Harmattan, 1990); Anne-Marie Grand, Victor Segalen. Le Moi et l'expérience du vide (Paris: Klincksieck, 1990); Robert Laliberté, L'imaginaire politique de Segalen (Québec: Institut québécois de la recherche sur la culture, Collection Edmond-de-Nevers, no. 8, 1989). Of these three, Marc Gontard's study is most relevant to my own concerns. See especially pp. 10-40. Henry Bouillier's Victor Segalen, reissued in 1986 by Mercure de France, remains the authoritative biographical study.

2. Victor Segalen, Les Immémoriaux (Paris: Seuil, 1985) (Collection Points).

3. For my understanding of the notions of 'subject,' 'experience,' and 'modernity' see section II below.

4. Victor Segalen, The Great Statuary of China (Chicago and London: University of Chicago Press, 1987).

$\underline{\mathbf{5}}$. Victor Segalen, Equipée (Paris: Gallimard, 1983) (in text: E).

6. G.S. Rousseau and Roy Porter (eds.), Exoticism in the Enlightenment (Manchester: Manchester University Press, 1990).

7. Victor Segalen, Essai sur l'exotisme (Montpellier: fata morgana, 1978) (in text: EE).

$\underline{\mathbf{8}}$. This new field of application for aesthetics goes hand in hand with the rise of bourgeois society. The gift of aesthetic sensibility was now reserved for a small number of exceptional individuals whose vision, in the wake of the social upheavals effected by modernization and industrialization, would guarantee the essential unity of humanity and nature. Their works functioned, however, in an autonomous realm, the refined sphere of art, because, in modernity, aesthetic concerns had undergone a process of separation from theoretical and 
political concerns. In Peter Bürger's terms, one can speak of art as institution from that time on, where institution refers to a social manner of production and reception unique to works of art. See Peter Bürger, Theory of the Avant-garde. Trans. Michael Shaw, Intro. Jochen Schulte-Sasse (Minneapolis: University of Minnesota Press, 1984).

9. Vicor Segalen, Les Synesthésies et l'école symboliste, Mercure de France (April 1902). This article has been reissued as: V.S., Les Synesthésies... (Montpellier: fata morgana, 1981). My page references are to the 1981 edition (in text: S).

10. In this attempt, Segalen unfortunately fails to distinguish between décadents and symbolistes so that, from a contemporary perspective, he muddles the profound differences separating these two literary movements. While Huysmans' decadent aesthetics can easily be identified with what I called aesthetic ideology above, that of Mallarmé, as the main representative of symbolism, can be seen in this fashion only if one excludes what is most interesting about it-such as his focus on the nature of language as an other/an outside to meaning itself. This stance radically throws into doubt notions like genius, experience, meaning, and representation. Since Segalen is primarily interested in tracing the role of synaesthesia in the symbolist school, one would do well to take a non-rigorous approach to his terminology and bear in mind the specific use he makes of the term 'symbolism.' Given these limitations, however, the essay in itself is an interesting document, for a closer look reveals how aestheticism (a term which I prefer to substitute for Segalen's use of 'symbolism'), under the spell of which it is written, exemplifies an aesthetics Segalen is soon to leave behind.

11. Princeton Encyclopedia of Poetry and Poetics (Princeton: Princeton University Press, 1974), 839-840.

12. Max Nordau, Dégénérescence (Paris: Alcan 1894).

13. Segalen's reply to Nordau's polemics is contained in the last section of his essay entitled 'Les synesthésies ne sont pas symptomes de dégénérescence mais de progrès.' See Synesthésies, 43-54.

Accueil Surfaces | Table des matières | Recherche Surfaces Home Page | Table of Contents | Search 